\title{
Pengaruh Pemberian Edukasi Gizi dan Kapsul Serbuk Daun Kelor (Moringa oleifera L.) terhadap Kenaikan Kadar Hemoglobin Remaja Putri di Universitas Pakuan
}

\author{
Lusi Indriani ${ }^{1}$, Cantika Zaddana ${ }^{1}$, Naufal Muharam Nurdin², dan Juniarti Sri Maryati Sitinjak' \\ 1Program Studi Farmasi, FMIPA, Universitas Pakuan, Bogor, Indonesia \\ ${ }^{2}$ Departemen Gizi Masyarakat, Fakultas Ekologi Manusia, Institut Pertanian Bogor, Bogor, Indonesia \\ Korespondensi: Lusi Indriani \\ Email: lusi.indriani@unpak.ac.id
}

Submitted : 05-09-2019, Revised : 22-10-2019, Accepted : 01-12-2019

\begin{abstract}
ABSTRAK: Anemia merupakan keadaan di mana kadar hemoglobin ( $\mathrm{Hb}$ ) dalam darah kurang dari $12 \mathrm{~g} / \mathrm{dL}$. Remaja khususnya remaja putri merupakan kelompok usia paling rentan mengalami penurunan hemoglobin, karena mereka mengalami menstruasi sehingga banyak kehilangan zat besi setiap bulannya. Hal ini dapat menyebabkan mudah lelah, mengantuk, pusing, daya konsentrasi cepat hilang, sehingga menghambat proses belajar dan prestasi. Salah satu bahan alam yang dapat digunakan sebagai alternatif untuk menaikkan kadar $\mathrm{Hb}$ adalah daun kelor (Moringa oleifera L.) yang mengandung protein, vitamin C, dan zat besi. Penelitian ini bertujuan untuk menilai pengaruh pemberian edukasi gizi dan kapsul serbuk daun kelor terhadap kenaikan hemoglobin remaja putri penderita anemia, serta membandingkan pengetahuan anemia responden sebelum dan sesudah edukasi. Metode yang digunakan dalam penelitian ini yaitu true experimental dengan desain pre- dan post-test. Responden adalah mahasiswi Fakultas MIPA Universitas Pakuan yang menderita anemia yang dibagi menjadi 2 kelompok perlakuan yaitu kelompok intervensi (mendapatkan edukasi dan kelor) dan kelompok kontrol (mendapatkan edukasi dan plasebo). Intervensi diberikan selama 30 hari. Hasil penelitian menunjukkan bahwa pemberian edukasi dan kapsul serbuk daun kelor dapat meningkatkan kadar hemoglobin secara bermakna dengan rata-rata kenaikan sebesar 1,76 $\pm 0,80 \mathrm{~g} / \mathrm{dL}$, sedangkan pada kelompok edukasi mengalami kenaikan sebesar 0,72 $\pm 0,97 \mathrm{~g} / \mathrm{dL}$. Dapat disimpulkan bahwa pemberian edukasi dan kapsul serbuk daun kelor dapat meningkatkan pengetahuan anemia dan kadar Hb responden secara bermakna.
\end{abstract}

Kata kunci: anemia; edukasi; hemoglobin; Moringa oleifera; remaja putri

\begin{abstract}
Anemia is a condition where the hemoglobin (Hb) level is lower than $12 \mathrm{~g} / \mathrm{dL}$. Teenagers are the most susceptible group experiencing a decrease in hemoglobin, especially teenage girls because they get menstruate so that they lose a lot of iron every month. It causes them become easily tired, drowsiness, dizziness, rapid concentration loss, then clearly inhibits the learning process and achievement. Natural ingredients as an alternative to increase $\mathrm{Hb}$ which is easily obtained and cultivated are Moringa oleifera L. leaves since they contain protein, vitamin $C$, and iron. This study aims to evaluate an increase of hemoglobin levels and the knowledge of anemia after giving education and capsules of moringa leaves powder. This is true experimental study with pre and posttest design. The respondents were female students with anemia which were divided to the intervention groups (getting education and kelor) and control groups (getting education and placebo). It was carried out for 30 days. The results showed that education and Moringa leaf powder capsules significantly increased hemoglobin levels by $1.76 \pm 0.80 \mathrm{~g} / \mathrm{dL}$, while the increase in the education group was $0.72 \pm 0.97 \mathrm{~g} / \mathrm{dL}$. It can be concluded that the education and Moringa leaf powder capsules can significantly increase the knowledge of anemia and Hb levels.
\end{abstract}

Keywords: education; Moringa oleifera; anemia; hemoglobin; teenage girl 


\section{Pendahuluan}

Hemoglobin $(\mathrm{Hb})$ adalah protein yang kaya zat besi. Hemoglobin memiliki afinitas terhadap oksigen, yang berfungsi membawa oksigen dari paru-paru ke jaringan-jaringan di dalam tubuh [1]. Hemoglobin merupakan bahan baku yang penting agar organ tubuh bekerja dengan baik. Bila pasokan $\mathrm{Hb}$ berkurang, tubuh menjadi mudah lesu dan mengantuk, akibatnya produktivitas menurun sehingga aktivitas sehari-hari terganggu. Hemoglobin dijadikan sebagai indikator terjadinya anemia. Seorang wanita dianggap mengalami anemia jika kadar $\mathrm{Hb}<12,0 \mathrm{~g} / \mathrm{dL}$. Anemia merupakan salah satu penyakit yang masih tinggi prevalensinya di Indonesia yaitu 18,4\% untuk remaja dengan rentang usia 15-24 tahun [2].

Remaja khususnya remaja putri merupakan kelompok usia yang paling rentan mengalami penurunan hemoglobin, karena mereka mengalami menstruasi yang artinya banyak zat besi (Fe) yang hilang melalui darah setiap bulannya. Mahasiswi merupakan periode remaja akhir dengan aktivitas yang padat, sehingga pada umumnya mereka memiliki pola makan yang tidak teratur. Menurut Briawan [3], hampir 50\% mahasiswa biasa makan dua kali sehari, dengan kombinasi makan pagi-malam atau siang-malam dengan frekuensi konsumsi lauk nabati lebih banyak dibandingkan dengan lauk pangan hewani. Pola makan yang tidak teratur serta asupan gizi yang tidak sesuai dapat menyebabkan penurunan hemoglobin. Dampak yang terjadi jika remaja memiliki nilai $\mathrm{Hb}$ rendah yaitu kesulitan belajar karena mudah merasa lelah, mengantuk, pusing, dan daya konsentrasi cepat hilang. Hal ini jelas dapat menghambat proses belajar dan prestasi [4].

Salah satu bahan alam yang dapat digunakan sebagai alternatif untuk mengatasi anemia serta mudah didapat dan dibudidayakan adalah daun kelor (Moringa oleifera L.). Tanaman ini mengandung protein, vitamin $\mathrm{C}$, dan zat besi yang tinggi dibandingkan sayuran sejenis lainnya. Daun kelor segar mengandung vitamin $C$ tujuh kali lebih ba- nyak dibandingkan buah jeruk, vitamin A empat kali lebih banyak dibandingkan wortel, kalsium empat kali lebih banyak dibandingkan susu, kalium tiga kali lebih banyak dibandingkan pisang, dan protein dua kali lebih banyak dibandingkan yogurt. Sementara itu, serbuk daun kelor kering mengandung vitamin A sepuluh kali lebih banyak dibandingkan wortel, kalsium tujuh belas kali lebih banyak dibandingkan susu, kalium lima belas kali lebih banyak dibandingkan pisang, zat besi dua puluh lima kali lebih banyak dibandingkan bayam, dan protein sembilan kali lebih banyak dibandingkan yogurt. Namun, kandungan vitamin $C$ lebih rendah yaitu setengah kali dibandingkan dengan jeruk [5].

Pemberian ekstrak daun kelor pada tikus wistar albino dengan dosis rendah $300 \mathrm{mg} / \mathrm{kg} \mathrm{BB}$ maupun dosis tinggi $600 \mathrm{mg} / \mathrm{kg}$ BB selama 21 hari telah terbukti dapat meningkatkan hemoglobin [6]. Penelitian klinis telah dilakukan oleh Ponomban dkk. [7] yang melakukan pemberian kapsul serbuk daun kelor dengan dosis $2 \times 2$ kapsul perhari (500 mg/kapsul) pada 35 orang wanita hamil penderita anemia selama 30 hari, terbukti dapat meningkatkan kadar hemoglobin. Berdasarkan beberapa penelitian tersebut, pemberian kapsul serbuk daun kelor disertai dengan edukasi diharapkan dapat memperbaiki kadar hemoglobin pada remaja putri penderita anemia.

Tujuan penelitian ini adalah membandingkan pengetahuan anemia responden sebelum dan sesudah edukasi, serta menganalisis pengaruh pemberian edukasi dan kapsul serbuk daun kelor terhadap kenaikan kadar hemoglobin remaja putri penderita anemia.

\section{Bahan dan metode}

\subsection{Bahan dan alat}

Bahan yang digunakan dalam penelitian ini adalah daun kelor segar yang diperoleh dari Balai Penelitian Tanaman Rempah dan Obat (BALITTRO) sebanyak $20 \mathrm{~kg}$, cangkang kapsul no. 0 , dan gula halus sebagai plasebo. 
Alat yang digunakan meliputi alat pengukur hemoglobin (Easy Touch $®$ ), strip hemoglobin (Easy Touch ${ }^{\circledR}$ ), timbangan analitik (Lab Pro ${ }^{\circledR}$ ), oven (Memmert $\AA$ ), tanur (Vulcan A-550®), dan grinder (Philips $®)$.

\subsection{Metode penelitian}

Penelitian ini menggunakan rancangan true experimental dengan desain pre- dan post-test dengan pendekatan prospektif untuk menilai pengaruh pemberian edukasi dan kapsul serbuk daun kelor terhadap peningkatan kadar hemoglobin remaja putri di Fakultas MIPA Universitas Pakuan yang menderita anemia. Keadaan awal setiap kelompok eksperimen ditunjukkan melalui pengukuran aktivitas fisik, pola konsumsi, dan tingkat stres dengan pengisian kuesioner, serta pre-test tentang pengetahuan anemia.

\subsubsection{Populasi dan sampel}

Populasi dalam penelitian ini adalah remaja putri di Fakultas MIPA Universitas Pakuan Bogor yang bersedia menjadi responden dalam penelitian setelah diberikan penjelasan secara singkat mengenai penelitian melalui Case report form (CRF) yaitu lembaran penarikan responden yang disertai surat informed consent. Penarikan sampel dari seluruh populasi remaja putri di Fakultas MIPA adalah tahap awal skrining untuk mengetahui kesediaan mereka menjadi responden dalam penelitian ini, setelah itu dilihat apakah responden sesuai dengan kriteria inklusi. Kriteria inklusi yaitu remaja putri di Fakultas MIPA dengan usia 18-21 tahun yang menderita anemia di luar menstruasi. Kriteria eksklusi dalam penelitian ini yaitu memiliki riwayat penyakit kronis, sedang mengkonsumsi vitamin $\mathrm{C}$, asam folat, dan zat besi. Skrining ini dilakukan untuk memisahkan responden yang sesuai kriteria, kemudian dilakukan pengukuran kadar hemoglobin pada setiap responden yang terpilih, dengan syarat nilai $\mathrm{Hb}$ 10-11 g/dL. Responden kemudian diberikan pre- test berupa kuesioner untuk mengukur tingkat pengetahuan tentang anemia, tingkat stres, dan aktifitas fisik, setelah itu jumlah responden yang telah terpilih dikelompokkan menjadi 2 dengan jumlah yang sama di setiap kelompoknya yaitu, kelompok edukasi (kontrol) dan kelompok kapsul serbuk daun kelor dengan edukasi (intervensi).

\subsubsection{Persetujuan ethical clearance}

Penelitian ini telah mendapatkan persetujuan dari komisi etik Fakultas Kedokteran Universitas Katolik Indonesia Atma Jaya dengan nomor surat 09/06/KEP-FKUAJ/2018.

\subsubsection{Pembuatan kapsul serbuk daun kelor}

Daun kelor segar yang diperoleh dari BALITTRO sebanyak $20 \mathrm{~kg}$ dipanen beserta tangkainya, kemudian dicuci di bawah air mengalir, setelah itu dilakukan penirisan agar air setelah pencucian berkurang, kemudian dilakukan pengeringan dengan menggunakan oven pada suhu di bawah $45^{\circ} \mathrm{C}$. Daun yang sudah kering dapat dicirikan dengan daunnya yang rapuh dan mudah dihancurkan. Daun yang sudah kering dipisahkan dari tangkainya lalu dihaluskan menggunakan grinder dan diayak dengan ayakan Mesh 100. Serbuk yang sudah halus disimpan dalam wadah kedap udara dan terhindar dari panas, kelembaban, dan cahaya untuk menghindari pertumbuhan mikroorganisme.

\subsubsection{Pengumpulan data}

Pengetahuan anemia dari kedua kelompok perlakuan diukur menggunakan kuesioner dari Aditian [8] yang telah dimodifikasi lalu dilakukan validasi dengan nilai reliabilitas 0,798 . Data aktivitas fisik didapat dengan pengisian daily activity yang dibagi menjadi 3 kategori yaitu aktifitas ringan, aktifitas sedang, dan aktifitas berat yang diukur dengan Physical Activity Level (PAL) atau tingkat aktivitas fisik dan Physical Activity Ratio (PAR) atau jumlah energi yang dikeluarkan un- 
tuk tiap jenis kegiatan per satuan waktu tertentu. Data pola konsumsi yang mencakup kebiasaan makan dan tingkat kecukupan gizi diperoleh dengan wawancara dan Food Frequency Questionnaire (FFQ), serta tingkat kecukupan gizi berupa protein, serat, makanan jadi/jajanan, vitamin C, vitamin B12, dan asam folat yang diukur dengan Food Recall 2 x 24 jam pada hari libur dan hari biasa. Data tingkat stres diperoleh berdasarkan kuesioner Depression Anxiety Stress Scale (DASS) yang terdiri dari 4 kategori yaitu normal, stres ringan, stres sedang, dan stres berat. Data pribadi diperoleh dengan pengisian lembar biodata responden dan dibuat catatan harian/diary yang digunakan untuk pencatatan jadwal minum suplemen setiap hari oleh responden.

\subsubsection{Pemberian suplemen dan aturan minum}

Dosis bubuk daun kelor yang digunakan pada penelitian Ponomban dkk. adalah 2 x 2 kapsul/ hari, satu kapsul berisi 500 mg bubuk daun kelor [7]. Pada penelitian ini dosis yang digunakan yaitu 1 x 3 kapsul, satu kapsul berisi 700 mg serbuk daun kelor, sehingga dosis perhari adalah 2100 mg. Suplemen diserahkan kepada responden setiap 3 hari sekali sebanyak 9 kapsul, sehingga untuk pemberian suplemen selama 30 hari dilakukan 10 kali penyerahan selama penelitian. Tujuan dilakukan penjadwalan tersebut agar peneliti dapat mengetahui gejala/keluhan yang dirasakan responden terhadap suplemen yang diberikan sekaligus untuk mengontrol kepatuhan dan untuk menghindari kecerobohan responden dalam penyimpanan kapsul serbuk daun kelor dan kapsul plasebo. Setiap hari dilakukan pemantauan jadwal konsumsi suplemen melalui reminder dalam grup diskusi online (whatsapp group).

\subsection{Analisis data}

Data yang diperoleh diberikan kode sesuai dengan kategorinya, kemudian dianalisis secara statistik menggunakan analisis univariat dan bivariat. Analisis univariat digunakan untuk memperoleh gambaran distribusi frekuensi serta pro- porsi dari variabel yang diteliti meliputi karakteristik responden (umur, tinggi badan, berat badan, usia menstruasi pertama, dan lama menstruasi), kadar hemoglobin, tingkat pengetahuan, aktivitas fisik, asupan besi (Fe), asupan vitamin B12, dan tingkat stres responden sebelum diberikan edukasi dan suplemen kelor atau plasebo. Analisis bivariat dengan uji Wilcoxon digunakan untuk menguji perbedaan kadar hemoglobin dan tingkat pengetahuan responden sebelum dan setelah pemberian edukasi dan suplemen kelor atau plasebo.

\section{Hasil dan pembahasan}

\subsection{Karakteristik responden}

Responden pada penelitian ini diambil dari populasi remaja putri di Fakultas Matematika dan Ilmu Pengetahuan Alam (FMIPA) dengan umur 18-21 tahun. Pengambilan sampel dimulai dengan skrining pengukuran kadar hemoglobin pada 425 orang calon responden, sehingga diperoleh 50 orang yang menderita anemia dari jumlah keseluruhan yang diperiksa. Jumlah responden dibagi menjadi 2 kelompok yaitu kelompok eksperimen sebanyak 25 orang dan kelompok kontrol sebanyak 25 orang. Teknik pemberian obat adalah secara double blind yaitu setiap obat memiliki kode untuk menjamin responden menerima obat yang sama. Kelompok eksperimen diberikan edukasi dan kapsul serbuk daun kelor, sedangkan kelompok kontrol diberikan edukasi dan kapsul plasebo yang berisi tepung gula dengan waktu intervensi selama 30 hari. Setelah 30 hari, tersisa 46 responden yang dapat menyelesaikan intervensi, dan drop out sebanyak 4 orang karena alasan tingkat kepatuhan konsumsi kapsul daun kelor atau plasebo yang kurang dari 60\%. Karakteristik responden yang meliputi usia, berat badan, tinggi badan, usia menstruasi pertama (menarche), dan lama menstruasi dapat dilihat pada Tabel 1.

Data pada Tabel 1 menunjukkan bahwa ratarata umur responden kelompok intervensi dan kelompok kontrol masing-masing adalah 19,70 
Tabel 1. Karakteristik responden yang mendapat edukasi dan kapsul daun kelor atau plasebo

\begin{tabular}{llll}
\hline Karakteristik responden & \multicolumn{2}{l}{ Kelompok } & p-value \\
\cline { 2 - 3 } & Intervensi & Kontrol & \\
\hline Umur (tahun) & $19,70 \pm 0,63$ & $19,56 \pm 0,59$ & 0,47 \\
Berat badan (kg) & $52,65 \pm 8,08$ & $51,48 \pm 6,91$ & 0,60 \\
Usia (mean \pm SD) & $57,26 \pm 9,24$ & $55,98 \pm 9,54$ & 0,22 \\
Tinggi badan (cm) & $152,26 \pm 5,60$ & $153,65 \pm 6,56$ & 0,44 \\
Usia menarche (tahun) & $13,48 \pm 0,73$ & $12,87 \pm 0,81$ & 0,01 \\
\hline Lama menstruasi (hari) & $9,04 \pm 3,89$ & $9,87 \pm 4,00$ & 0,48 \\
\hline
\end{tabular}

Keterangan: kelompok intervensi mendapat edukasi dan kapsul daun kelor; kelompok kontrol mendapat edukasi dan kapsul plasebo

Tabel 2. Hasil pengukuran variabel awal sebelum pemberian edukasi dan kapsul daun kelor atau plasebo

\begin{tabular}{llll}
\hline Variabel & \multicolumn{2}{l}{ Kelompok } & K-value \\
\cline { 2 - 3 } & Intervensi & Kontrol & \\
\hline Hemoglobin (mg/dL) & $10,65 \pm 0,69$ & $11,18 \pm 0,51$ & 0,006 \\
Pengetahuan & $64,52 \pm 19,36$ & $68,43 \pm 18,10$ & 0,428 \\
Asupan Fe (\%) & $24,08 \pm 0,11$ & $24,10 \pm 0,12$ & 0,956 \\
Asupan Vitamin B12 (\%) & $23,80 \pm 0,16$ & $29,64 \pm 0,17$ & 0,252 \\
Tingkat stres & $22,61 \pm 9,48$ & $19,78 \pm 6,42$ & 0,310 \\
\hline
\end{tabular}

Keterangan: kelompok intervensi mendapat edukasi dan kapsul daun kelor; kelompok kontrol mendapat edukasi dan kapsul plasebo

dan 19,56 tahun dengan rentang umur mulai dari 19-21 tahun; rata-rata berat badan responden adalah 52,65 dan 51,48 kg dengan rentang antara 42-69 kg; rata-rata tinggi badan responden adalah 152,26 dan 153,65 cm dengan rentang antara 144-67 cm; rata-rata umur menarche responden adalah 13,48 dan 12,87 tahun, dengan umur pertama kali mengalami menstruasi berkisar pada usia 12-15 tahun, serta rata-rata lama menstruasi adalah 9,04 dan 9,87 hari. Berdasarkan independent sampel t-test diperoleh bahwa tidak ada perbedaan nyata antar kelompok ( $p>0,05$ ) pada karakteristik umur, berat badan, tinggi badan, dan lama menstruasi. Hal ini menunjukkan bahwa karakteristik responden dari umur, berat badan, tinggi badan, dan lama mentruasi adalah homogen sehingga tidak ada pengaruh terhadap kenaikan kadar hemoglobin, namun pada usia menstruasi pertama terdapat perbedaan antara kedua kelompok. Usia menarche dapat dipengaruhi oleh status gizi dan berat badan lahir [9].

\subsection{Hasil pembuatan simplisia daun kelor}

Daun kelor dipanen pada pagi hari dengan memetik daun beserta ranting tanaman. Bagian ranting kemudian dipisahkan setelah proses pengeringan. Serbuk simplisia daun kelor memiliki karakteristik warna hijau, rasa agak sepat, dan aroma khas lemah. Hasil yang diperoleh sesuai dengan standar Farmakope Herbal Indonesia [10]. Sebanyak $20 \mathrm{~kg}$ daun kelor segar dikeringkan menggunakan oven pada suhu $45^{\circ} \mathrm{C}$, kemudian dihaluskan menggunakan grinder sehingga diperoleh serbuk simplisia daun kelor sebanyak 3,11 kg dengan rendemen simplisia sebesar $15,55 \%$. Rata-rata hasil pengujian susut pengeringan pada serbuk simplisia daun 
kelor yaitu 7,68\% yang menunjukkan bahwa serbuk simplisia telah memenuhi syarat susut pengeringan untuk daun kelor yaitu tidak lebih dari 12\% [10]. Rata-rata kadar abu simplisia yang diperoleh adalah 6,65\%. Hasil tersebut memenuhi syarat untuk kadar abu pada serbuk simplisia daun kelor yaitu tidak lebih dari 7,5\% [10].

\subsection{Hasil pengukuran variabel awal penelitian}

Jenis variabel yang diukur pada awal penelitian (Tabel 2) adalah tingkat pengetahuan anemia, pola konsumsi (asupan Fe dan vitamin B12), dan tingkat stres. Analisis non parametrik Mann Whitney dilakukan untuk mengetahui apakah terdapat perbedaan di antara kelompok intervensi dan kontrol untuk setiap variabel sebelum diberikan intervensi. Hasilnya diperoleh bahwa tidak ada perbedaan nyata antar kedua kelompok $(p>0,05)$ untuk variabel pengetahuan, pola konsumsi (asupan Fe dan vitamin B12), dan tingkat stres, namun pada variabel kadar hemoglobin terdapat perbedaan antar kedua kelompok sebelum diberikan intervensi $(p<0,05)$. Data kadar hemoglobin sebelum intervensi tidak homogen antar kelompok disebabkan pengelompokan responden dilakukan secara acak, dan tidak diatur oleh peneliti.

\subsection{Pengaruh edukasi terhadap pengetahuan tentang anemia}

Sebelum pemberian edukasi, dilakukan pengisian kuesioner (pre-test) untuk menilai sejauh mana tingkat pengetahuan responden tentang anemia. Pengetahuan anemia diperoleh menggunakan kuesioner yang telah dimodifikasi dari kuesioner Aditian [8] dengan nilai reliabilitas 0,798. Kemudian setelah pemberian edukasi semua responden diukur kembali pengetahuan mereka tentang anemia (post-test). Hasil pengukuran pengetahuan tentang anemia disajikan pada Tabel 3.

Hasil uji hipotesis komparatif dengan uji Wilcoxon signed rank test menunjukkan bahwa terdapat perbedaan nyata antara tingkat
Tabel 3. Perbandingan pengetahuan tentang anemia pada responden yang mendapat edukasi dan kapsul daun kelor atau plasebo

\begin{tabular}{lll}
\hline $\begin{array}{l}\text { Pengetahuan } \\
\text { anemia }\end{array}$ & Intervensi & Kontrol \\
\hline Pre & $64,52 \pm 19,36$ & $68,43 \pm 18,10$ \\
Post & $87,96 \pm 4,77$ & $87,17 \pm 5,53$ \\
$p$-value & 0,000 & 0,000 \\
\hline
\end{tabular}

Keterangan: kelompok intervensi mendapat edukasi dan kapsul daun kelor; kelompok kontrol mendapat edukasi dan kapsul plasebo

pengetahuan sebelum edukasi dengan sesudah edukasi dengan nilai significancy 0,000 (p $<0,05)$. Dapat dilihat bahwa skor rata-rata pengetahuan anemia pada kelompok intervensi sebelum diberikan edukasi adalah 64,52 namun setelah diberikan edukasi meningkat dengan rata-rata 87,96. Sedangkan kelompok kontrol sebelum diberikan edukasi adalah 68,43 dan setelah diberikan edukasi menjadi 87,17. Hal ini sesuai dengan penelitian Sukmawati (11) bahwa terdapat perbedaan pengetahuan ibu hamil sebelum edukasi $(51,97)$ dengan sesudah edukasi $(64,03)$ mengenai pencegahan dan penanganan ibu hamil di Puskesmas Haurpanggung.

Pemberian edukasi dapat meningkatkan pengetahuan seseorang, hal ini didukung oleh Buzarudina [12] yang menyatakan bahwa pemberian penyuluhan dapat meningkatkan pengetahuan remaja. Peningkatan pengetahuan diharapkan dapat memunculkan motivasi intrinsik pada remaja putri untuk konsumsi nutrisi vitamin B12 sebagai upaya pencegahan kekurangan vitamin B12. Pengetahuan gizi berperan terhadap cara memilih makanan dengan baik sehingga dapat mencapai keadaan gizi yang cukup [13]. Penelitian Haryono [14] menunjukkan bahwa terdapat pengaruh pendidikan anemia audio visual tanpa atau dengan leaflet dalam meningkatkan pengetahuan anemia pada remaja putri.

\subsection{Pengaruh pemberian edukasi dan serbuk}




\section{daun kelor terhadap kadar hemoglobin}

Pengecekan kadar hemoglobin (Hb) dilakukan oleh dokter di Unit Pelayanan Kesehatan Fakultas Matematika dan Ilmu Pengetahuan Alam. Sebaran data kadar $\mathrm{Hb}$ pada 2 kelompok sebelum pemberian intervensi diuji dengan KolmogorovSmirnov Test dan hasilnya menunjukkan bahwa data terdistribusi normal $(p=0,258)$. Oleh karena itu, untuk mengetahui perbandingan kadar $\mathrm{Hb}$ sebelum dan sesudah intervensi dilakukan pengujian menggunakan Paired t-test.

Tabel 4 menunjukkan bahwa terjadi kenaikan kadar $\mathrm{Hb}$ sesudah pemberian intervensi. Pada kelompok intervensi, sebelum pemberian intervensi rata-rata kadar $\mathrm{Hb}$ adalah 10,65 \pm 0,69 $\mathrm{g} / \mathrm{dL}$ dan setelah pemberian intervensi meningkat menjadi 12,40 $\pm 0,59 \mathrm{~g} / \mathrm{dL}$, dengan kenaikan ratarata sebanyak 1,75 g/dL. Pada kelompok kontrol sebelum diberikan intervensi rata-rata kadar $\mathrm{Hb}$ adalah $11,18 \pm 0,51 \mathrm{~g} / \mathrm{dL}$ dan setelah pemberian intervensi meningkat menjadi $11,90 \pm 0,42 \mathrm{~g} /$ dL dengan kenaikan rata-rata sebesar 0,72 g/ dL. Hasil uji hipotesis komparatif dengan Paired t-test terhadap kadar $\mathrm{Hb}$ sebelum dan sesudah intervensi pada masing-masing kelompok adalah sama yaitu dengan nilai signifikansi 0,000 ( $p<0,05)$. Dapat disimpulkan bahwa terdapat kenaikan kadar $\mathrm{Hb}$ yang bermakna pada kelompok intervensi yang mendapatkan daun kelor dan edukasi, serta pada kelompok kontrol yang hanya mendapatkan edukasi.

Hasil uji hipotesis komparatif dengan Unpaired

Tabel 4. Perbandingan kadar hemoglobin responden yang mendapat edukasi dan kapsul daun kelor atau plasebo

\begin{tabular}{lll}
\hline Pengukuran & \multicolumn{2}{l}{ Kadar $\mathbf{H b}(\mathrm{g} / \mathbf{d L})$} \\
\cline { 2 - 3 } & Intervensi & Kontrol \\
\hline Pre & $10,65 \pm 0,69$ & $11,18 \pm 0,51$ \\
Post & $12,40 \pm 0,59$ & $11,90 \pm 0,42$ \\
$p$ & 0,000 & 0,000 \\
\hline
\end{tabular}

Keterangan: kelompok intervensi mendapat edukasi dan kapsul daun kelor; kelompok kontrol mendapat edukasi dan kapsul plasebo t-test terhadap kenaikan kadar $\mathrm{Hb}$ pada kelompok intervensi $(1,75 \pm 0,80 \mathrm{~g} / \mathrm{dL})$ dan kelompok kontrol $(0,72 \pm 0,97)$ diperoleh nilai signifikansi $0,000 \quad(p<0,05)$. Artinya terdapat perbedaan yang bermakna antara kenaikan Hb kelompok intervensi dengan kelompok kontrol. Hasil ini menunjukkan bahwa kelompok intervensi yang mendapatkan serbuk daun kelor dan edukasi mengalami kenaikan kadar hemoglobin yang lebih tinggi dibandingkan kelompok plasebo yang hanya mendapatkan edukasi. Penelitian ini sejalan dengan hasil penelitian Ponomban [7] yang menyatakan bahwa pemberian kapsul bubuk daun kelor selama 30 hari dapat meningkatkan kadar hemoglobin pada wanita hamil. Penelitian lain yang memberikan ekstrak air daun kelor sebanyak $1400 \mathrm{mg}$ per hari selama 3 minggu pada wanita yang mengalami anemia defisiensi besi terbukti dapat meningkatkan kadar hemoglobin sebesar 0,794 $\pm 0,81 \mathrm{~g} / \mathrm{dL}$ [15].

Selama penelitian terdapat 1 responden pada kelompok intervensi yang menyampaikan beberapa keluhan seperti pusing, kepala terasa berat dan merasa lemas. Efek ini terjadi diduga karena responden mengkonsumsi kapsul serbuk daun kelor dalam keadaan perut kosong (sebelum makan). Belum ada penelitian mengenai efek samping penggunaan daun kelor.

\section{Kesimpulan}

Pemberian edukasi meningkatkan pengetahuan anemia responden secara bermakna. Pemberian edukasi dan kapsul serbuk daun kelor meningkatkan kadar hemoglobin secara bermakna dengan rata-rata kenaikan sebesar 1,76 $\pm 0,80 \mathrm{~g} /$ dL, sedangkan pada kelompok edukasi mengalami kenaikan sebesar 0,72 $\pm 0,97 \mathrm{~g} / \mathrm{dL}$.

\section{Ucapan Terima Kasih}

Peneliti menyampaikan terima kasih kepada Lembaga Penelitian dan Pengabdian pada Masyarakat (LPPM) Universitas Pakuan yang 
telah mendanai penelitian ini.

\section{Daftar Pustaka}

1. Pearce EC. Anatomi dan Fisiologis untuk Para Medis. Cetakan Kedua puluh Sembilan. Jakarta: PT. Gramedia Pustaka Utama; 2009: 141-2.

2. Kementerian Kesehatan RI. Riset Kesehatan Dasar; RISKESDAS. Jakarta: Balitbang Kemenkes RI; 2013.

3. Briawan D. Efikasi suplementasi besimultivitamin terhadap perbaikan status Besi remaja wanita Bogor. Institut Pertanian Bogor; 2008.

4. Ahmadi dan Supriyono. Psikologi Belajar. Jakarta: PT. Rineka Cipta; 2008.

5. Fahey JW. Moringa oleifera: A Review of the medical evidence for its nutritional, therapeutic, and prophylactic properties part 1. Trees Life J. 2005;1(5):21205-85.

6. Nku-Ekpang OT, Nwaehujor CO, Ofem OE, Ezekiel J. Effect of Moringa oleifera Lam. Ethanol Leaf Extract on Hematology in Phenylhydrazineinduced Anemic Albino Wistar Rats. American Journal of Pharmacological Sciences. 2015;3(3):67-73.

7. Ponomban SS, Walalangi R, dan Harikedua VT. Efektifitas Suplementasi Bubuk Daun Kelor (Moringa oleifera) Terhadap Peningkatan Kadar Hemoglobin Pada Ibu Hamil. GIZIDO-Jurnal Ilimiah Gizi. 2013;5(1).

8. Aditian N. Faktor-Faktor Yang Mempengaruhi Kejadian Anemia Gizi Remaja Putri SMP 133 di Pulau Pramuka Kepulauan Seribu. Media Gizi Kesehatan Masyarakat Indonesia. 2009;7(2):816.
9. Putra IGNE, Pradnyani PE, Pragmaningtyas MS, Kusumadewi NMC, Widarini NP. Faktor-Faktor yang Mempengaruhi Umur Menarche pada Siswi Sekolah Dasar di Kota Denpasar (Factors Associated With Age of Menarche Among Primary School Girls in Denpasar City). BIMKMI. 2016;4(1):31-8.

10. Kementerian Kesehatan RI. Farmakope Herbal Indonesia. Kementerian Kesehatan Republik Indonesia; 2013.

11. Sukmawati S, Mamuroh L, Nurhakim F. Pengaruh Edukasi Pencegahan dan Penanganan Anemia terhadap Pengetahuan dan Sikap Ibu Hamil. Jurnal Keperawatan BSI. 2019;7(1):42-7.

12. Buzarudina F. Efektivitas Penyuluhan Kesehatan Reproduksi Remaja Terhadap Tingkat Pengetahuan Siswa SMAN 6 Kecamatan Pontianak Timur Tahun 2013. Jurnal Mahasiswa PSPD FK Universitas Tanjungpura. 2013;3(1)

13. Imran $\mathrm{N}$, Indriasari $\mathrm{R}$, Najamuddin $\mathrm{U}$. Pengetahuan dan Sikap Tentang Anemia dengan Status Hemoglobin Remaja Putri di SMA Negeri 10 Makasar. Artikel Hasil Penelitian. Makasar: Universitas Hasanudin; 2014.

14. Haryono D, Hanim D, dan Kusnandar. Pengaruh Pendidikan Anemia Gizi Audio Visual dan Leaflet terhadap Tingkat Pengetahuan dan Perilaku Mengkonsumsi Tablet Fe Serta Kadar Hemoglobin pada Remaja Putri. Jurnal Gizi dan Kesehatan. 2014;1(2).

15. Suzana D, Suyatna FD, Azizahwati, Andrajati R, Sari SP, Mun'im A. Effect of Moringa oleifera Leaves Extract Against Hematology and Blood Biochemical Value of Patients with Iron Deficiency Anemia. Journal of Young Pharmacists. 2017;9(1) Suppl:s79-s84. 